\title{
Evolution of the Abortion Law and its Practice in Poland Against the Background of the Current Legal Framework in New Zealand
}

Author: Eska-Mikołajewska, J.

To cite this article: Eska-Mikołajewska, J. (2021). Evolution of the Abortion Law and its Practice in Poland Against the Background of the Current Legal Framework in New

Zealand. National Security Journal, 3(1). doi:10.36878/nsj202100405.02

To link to this article: https://doi.org/10.36878/nsj20210405.02

View CrossRef data: https://search.crossref.org/?q=10.36878\%2Fnsj20210405.02 


\title{
EVOLUTION OF THE ABORTION LAW AND ITS PRACTICE IN POLAND AGAINST THE BACKGROUND OF THE CURRENT LEGAL FRAMEWORK IN NEW ZEALAND
}

\author{
Justyna Eska-Mikołajewska ${ }^{1}$
}

\begin{abstract}
The article presents a comparative study on abortion legislation in Poland and New Zealand. It includes a historical overview of the social and political influences shaping the contemporary approach to abortion in these countries. The aim of the article is to discuss the changes to the Polish and New Zealand abortion legislation and the current procedures required to access abortion. This article highlights differences in approaches to this issue in both countries where abortion laws have evolved recently in opposite directions. In New Zealand, after removing abortion from the Crimes Act 1961, abortion ceased to be the subject to criminal law, while in Poland where one of the strictest anti-abortion laws had been in force already, a ban was imposed on abortion which made it practically impossible for women to access legal abortions.
\end{abstract}

Keywords: Abortion Ban, Poland, Abortion Legislation Reform, Abortion Legislation Act, New Zealand

\section{Introduction}

Determining the initial moment of life creates some dilemmas not only for philosophers, theologians, representatives of the clergy, doctors or lawyers, but also for politicians who discuss and initiate changes to legal Acts concerning the protection of the right to life. This is of fundamental importance in the aspect of allowing termination of pregnancy. In contemporary legal systems there are two models of regulating the phenomenon of

1 Dr Justyna Eska-Mikołajewska is an assistant professor at the Department of Political Studies at the University of Economics, Krakow (Poland). She was hosted as a visiting scholar at the Centre for Defence and Security Studies on Massey University's Wellington campus. During her stay in New Zealand, she worked on the research for a co-authored book on the national security of New Zealand in the changing security environment of the Asia-Pacific region. She has been cooperating with academics from the Centre in various projects, including the portal Przemiany ustrojowe, which specialises in political and constitutional issues of contemporary states. Contact by email eskaj@uek.krakow.pl. 
abortion. The first is characterised by granting of nasciturus legal protection already in the period of its fetal life. According to this model, abortion is possible, but its availability is limited in the light of the mandatory legal provisions. In the second model, the fetus in the early stages of pregnancy is treated as part of mother's body and therefore a woman can decide about its fate up to a clearly defined moment (most often up to 12 weeks). ${ }^{1}$

In Poland and New Zealand, termination of pregnancy was the subject to some significant limitations, which made both countries examples of the practical application of the first of the above-mentioned models. Abortions were the subject to a criminal sanction if they were performed outside the indicated grounds for termination of pregnancy. There were various reasons for criminalising abortion in these countries. Nonetheless, Poland as the only country in the former Communist Bloc and New Zealand were among the last developed countries - apart from mini-European states and Ireland - that are a stronghold of the restrictive abortion laws.

According to the position of UN experts, having an ability to make their own decisions by women about pregnancy is at the very core of fundamental rights, including the right to equality, privacy as well as physical and mental integrity. In this perspective, the criminalisation of abortion could be considered a violation of a woman's right to life, because it compels women to resort to unsafe abortion. ${ }^{2}$ Based on the World Health Organization data, criminalising the abortion and doctors' fear of entering into conflict with the law, does not limit the number of abortions. On the contrary, it causes more illegal abortions. ${ }^{3}$ As a result, the termination of pregnancy becomes the third most common cause of death in pregnant women in the world. ${ }^{4}$ In this context, de-criminalisation in the form of removing criminal sanctions against abortion and establishing a broad and strictly defined legal framework for legal abortions becomes - with access to sex education in schools and partially refunded or free contraception - one of the most effective tool to reduce the number of illegal (and often dangerous) abortions. ${ }^{5}$

\section{From the most liberal laws to the "abortion compromise"}

The provisions of the abortion law in Poland have evolved over the years. It should be emphasized that Polish abortion legislation in the 1930s, although very restrictive, as both the mother and the abortionist were punished, was one of the most liberal in Europe. ${ }^{6}$ There were only two exceptions to punishment: due to medical indications or when pregnancy occurred as a result of rape, incest or sexual intercourse with a minor under 15 years old. ${ }^{7}$ Pursuant to the ordinance of the President of the Republic of Poland of September 25, 1932 on the performance of medical practice, it became obligatory to determine a medical reason for termination of pregnancy verified by two doctors other than the one performing the procedure. ${ }^{8}$ The only period when abortions could be performed to an unlimited extent ("on demand") were the years of the Nazi occupation (1943-1945). ${ }^{9}$ The Nazi's rationale for such a liberal approach to abortion 
was based on paradigm of "Social Darwinism" that considered to be scientific. The aim of Nazi policy on abortion was to ensure the extermination of those nations whom were referred to as "inferior genetic stock." They included the communities of Eastern Europe, including the Polish, and Jews. ${ }^{10}$

The next stage of liberalisation of the abortion law was the period of the People's Republic of Poland, officially initiated by the introduction of the new constitution in 1952, according to which the equal rights of women and men were guaranteed by the care of the mother and child and the protection of the pregnant woman. ${ }^{11}$ Shortly after the adoption of the Basic Law, on July, 1954, the Minister of Health issued an instruction that changed the criteria for determining the necessity of an abortion to the health of the pregnant woman. Pursuant to this Act, a hospital medical committee consisting of two to three doctors decided on the necessity to terminate the pregnancy for the health of the woman. ${ }^{12}$

Apart from Yugoslavia, where abortion laws existed since 1951, Poland, along with Hungary and Bulgaria, was one of the first countries in the former Eastern Bloc to legalise abortion. Thus, while termination of pregnancy for health reasons was allowed in the Soviet Union in 1955, Poland did so in 1956. The Act of 27 April $1956^{13}$ on the conditions for the admissibility of termination of pregnancy introduced the possibility of performing an abortion in three cases: a) when medical indications were in favor of termination of pregnancy; b) when the pregnancy was a result of a crime, and c) the difficulty of the living conditions of a woman. In the brief reference to this Act, it was emphasised that its purpose is to protect the health of a woman against the negative effects of abortion, performed in inappropriate conditions or by non-doctors. Both the medical indications and the difficult life conditions of the woman could only be determined by a doctor, while the existence of a reasonable suspicion that the pregnancy resulted from a crime was confirmed by the prosecutor in the form of a certificate.

In legal terms, the adoption of the 1956 Act also had certain effects as it repealed the previous articles 231-234 of the Criminal Code. They concerned the punishment of a woman for aborting a fetus or allowing another person to do so, committing such an act with the consent of the pregnant woman or assisting her in doing so, as well as aborting the fetus without the consent of the pregnant woman. It is noteworthy that the punishment facing a woman for abortion was more lenient than those of the third parties. The Act of 1956 introduced its own penal provisions concerning the penalisation of forcing a woman in any way to undergo an abortion and demanded doctors to perform the procedure only with the consent of the pregnant woman. ${ }^{14}$

The pre-World War Two Penal Code established broad grounds by excluding the punishability of abortion in comparison with other European countries at that time. It used the term "fetus removal" which was different from the 1956 Act that called the same 
act "termination of pregnancy". It was the mother's health condition that became the subject of the new Act, and the protection of the child's life began to be determined by her medical, legal and economic conditions.

Under this law, an abortion could be performed at a woman's request after submitting a statement concerning their life situation. In the context of the difficult living conditions of the woman, a simplified procedure was adopted for issuing a medical termination decision by the doctor, as it was done only on the basis of the woman's declaration stating the existence of these conditions. ${ }^{15}$ Due to the anticipated size of the phenomenon and insufficient hospital infrastructure in the country, the legislator de facto also left an emergency door: after being referred, the procedure could be performed anywhere by a qualified doctor with sufficient professional preparation. The purpose of introducing such a law was to discourage women from using the help of unqualified people. Doctors who terminated pregnancies during this time were only required to verify women's declarations until $1959 .{ }^{16}$

It can be assessed that during the period of the Polish People's Republic the permissibility of abortion was found to be easier to implement than to combat the causes of this phenomenon. In practice, after 1959 abortions were performed on a woman's request. ${ }^{17}$ Nevertheless, the Regulation of the Ministry of Health of 1959 imposed some new obligations on doctors. According to the regulation, doctors were to provide women with the addresses of institutions where pregnancy could be terminated, instruct them on how to prevent unwanted pregnancy, provide them with a prescription for an appropriate contraceptive, inform them about the need to report for check-ups after the abortion and periodically appearing in the "clinic for women and conscious motherhood", and to provide them with appropriate information materials on methods of pregnancy prevention. As the result, contraceptives became available and sex education was introduced in schools.

The high number of abortions due to social reasons proved that this procedure was an important technique for birth control in the Polish People's Republic. Importantly, according to the declarations introduced to the Constitution of the People's Republic of Poland in 1976, the state was to care "for the development of the nation, cares for the family, motherhood and upbringing of the young generation" and "cares for the health of the society". In the opinion of the government, the aforementioned amendments to the Constitution of 1976, however, did not provide sufficient justification for amending the 1956 Act on the conditions for the admissibility of abortion. ${ }^{18}$

The first more important attempt to limit broad access to abortion in Poland, under the 1956 Act, was the submission of a motion to the lower house of parliament (Sejm) to the People's Republic of Poland, in December 1977 by the Polish Committee for the Defence of Life, Family and Nation. The motion aimed to abolish the conditions permitting abortion. This initiative, supported by the then Primate of Poland, Stefan Wyszyński, 
was focused on the interest in this issue among the broadest possible circles of society, especially the clergy, doctors, lawyers and democratic opposition groups. However, it failed, as the Ministry of Health and Social Welfare announced there would be no legal changes, as the 1956 Act contributed to the reduction of the number of abortions and protected against abortions performed by people without proper qualifications. ${ }^{19}$

Another proposal aimed at limiting the possibility of performing abortions in Poland dates back to 1981 when the board of the Catholic Intelligentsia Club formulated the postulate of "practical action to protect and the right to life" as one of their principles. ${ }^{20}$ The club's roots went back to the "Solidarity" - the first independent trade union in Poland, as well as a civic movement inspired Christian values. "Solidarity" was established during a wave of strikes in the summer of 1980, however, it was officially registered in September 1980. ${ }^{21}$ In its Program Resolution in 1981 it described itself as a "moral movement rebirth of the nation". The benchmark for the movement were "values of Christian ethics" and the absolute authority was the person of John Paul II. ${ }^{22}$

The Szczecin Catholic Club requested that the existing provisions of the 1956 Act be replaced with a new parenthood protection Act. The Club activists associated with the then opposition ${ }^{23}$ had submitted a letter to the Sejm of the People's Republic of Poland on April 27, 1987. Soon after, on February 28, 1989, a draft law on the legal protection of a conceived child was submitted to the the Parliamentary Committee for Social Policy, Health and Physical Culture by Archbishop Bronisław Dąbrowski, then secretary of the Bishops' Conference and the team of experts from the Polish Episcopal Commission for Family Affairs. ${ }^{24}$ There is no doubt that this bill, read for the first time in the Sejm on May 10, 1989, and therefore during the Round-table talks, was a fully church - sponsored project.

The law restricting abortion after the fall of communism in 1989, became one of the priorities of the Catholic Church. The adoption of the new legal Act appeared quite realistic, as the Church was deeply embedded in politics and managed to establish itself as a defender of Polish democracy. At the turn of the 1970s and 1980s, all the outposts of the Open Church, in the form of related socio-cultural magazines such as Tygodnik Powszechny, Więź and Znak, participated in the campaign to repeal the 1956 Act. After 1989, the Catholic Church, which had provided key support to the pro-democracy movement during the transition period, firmly insisted that the newly appointed government should allow for the Church's position on social issues.

In relation to the ideological diversity of the environments constituting the so-called opposition, it can be presumed that the actual attitude of representatives of various opposition circles to the absolute ban on abortion could be different. Nevertheless, it was difficult to speak out openly against this ban in line with the position of the Catholic Church. It called the 1956 Act "criminal" and "Stalinist", pointing out that people introduced to the Sejm in 1952 by Stalin voted to legalize abortion similarly to other coun- 
tries of the former Communist Bloc. As the result, any explicitly proclaimed support for the Act was conceived as crossing a certain unspoken boundary between the socalled "we" and "they". It was the border that de facto organised the social imagination, constituting the basic element of legitimising the "Solidarity" movement. The division into "we" versus "they" became a key element in the electoral struggle in Poland at the threshold of the last decade of the $20^{\text {th }}$ century.

The importance of the election campaign of June 1989 was that it preceded the first partially free elections in the history of Poland after World War Two. One of its basic assumptions was to convince people that "they are faced with a clear choice - either Lech Wałęsa's team or the team that has been ruling Poland for over forty years". During that time, the Catholic Church in Poland had enormous social capital in the form of trust in the institutions of the Church (estimated at around 95 percent), as well as a high percentage of professed believers in Poland (around 93 percent). ${ }^{26}$ Although the involvement of the Church in the June 1989 campaign clearly confirmed the institutional and symbolic ties between the opposition and the Church, it was not automatically translated into public support for the anti-abortion law. ${ }^{27}$

It is important to note that at the time the feminist movement in Poland was still dormant. Women were practically absent from politics, which was confirmed by the fact that only two women took part in the Round Table talks on the 1956 Act and the Church motion in Poland in 1989. In 1991, the Federation for Women and Family Planning was established. It was the first Polish non-governmental organisation supporting women who fight for health and reproductive rights. ${ }^{28}$

The political situation, shaped after 1989, resulted in a break with the legal theories based on Marxism that had been in force so far, and a move towards the concept of natural law formulated in a personalistic spirit. According to it, the aim of all analysis and research directed at man is to emphasize the uniqueness of every human person, especially in the aspect of its subjectivity. ${ }^{29}$ In 1993 , the new law on family planning entered into force and was considered as a compromise between the vision of the Church and the secular authorities of the time. In accordance with the Act of 7 January 1993 on family planning, protection of the human fetus and conditions for permitting abortion, ${ }^{30}$ an abortion could be performed only in three cases: a) when pregnancy posed a threat to woman's life or health (with mental health actually not being taken into account); b) if there was a high probability of severe and irreversible damage to the fetus of a disease that threatens its life (abortion was possible for the fetus to achieve the ability to live independently outside the body of a pregnant woman, which meant about 22-24 weeks) or c) if pregnancy resulted from a prohibited act such as rape or incestuous intercourse (abortion was possible up to 12 weeks). 
What is particularly important is that from that moment on, abortion was stopped for socio-economic reasons. The access to abortion, compared to the freedom women enjoyed under the Communist rule, was thus significantly restricted. A significant proportion of women accepted this with dissatisfaction, which resulted in protests and the collection of 1.7 million signatures on the motion for a referendum on the matter. ${ }^{31}$ It aimed to show the opinion of the citizen and to oblige the legislators to respect the decision thus made. However, the parliamentary draft regarding this referendum was lost in the Sejm of the $1^{\text {st }}$ term, being the embodiment of the extreme fragmentation of the political scene at that time, albeit dominated by right-wing groups with a clearly anti-abortion approach. ${ }^{32}$

\section{Rejecting of the existing status quo}

Abortion Law 1993, which was a contract between politicians and church officials, has survived in Poland for several decades. Life protection of an unborn child, in the light of the statutory regulation adopted in 1993, was treated as the implementation of a subjective right, thus implicitly confirmed the legal subjectivity of the unborn child. The new Act of 1993 provided the ground for a total ban on termination of pregnancy. According to the new Act, the person performing the procedure could be imprisoned (up to five years) and the woman terminating the pregnancy could face a jail sentence up to three years.

The law regulating termination of pregnancy in Poland from 1993 was classified in the second category in terms of radicalness in the world (together being a group of 56 countries, i.e. $14 \%$ population). ${ }^{33}$ Even though it was one of the most restrictive in Europe, it is assumed that in the Poland's transition period to democracy a relatively permanent "abortion compromise" was reached. Nevertheless, in the 1990s and at the beginning of the 21 st century, several bills were submitted to the Sejm by both the right-wing parties who opposed any changes to the existing legislation as well as the centrist and the leftwing parties who supported changes at least in part.

The first change was to restore the possibility of performing an abortion if the woman was in a difficult life or personal situation from the 1956 Act. On August 30, 1996, the amendment to the law on family planning was passed, which allowed termination of pregnancy. In such cases, a pregnant woman was required to submit a written statement and consult with another primary care physician or other authorized person than the one who was to perform the abortion. It could be performed if the woman maintained her intention 3 days after the consultation. Originally, the March 1, 1993 version of the Act, contained the confirmation of the inherent right to life of every human from the moment of conception, with a guarantee of legal protection of the child's life and health. After the amendment, "the right to life began to be protected, also in the prenatal phase within the limits specified in the Act." 34 
The circumstances excluding the unlawfulness of termination of pregnancy were then transferred from the Criminal Code to a specially added section 4a (1) of the Act on family planning, protection of the human fetus and conditions for permitting termination of pregnancy. ${ }^{35}$ The amendment to the Act allowing for termination of pregnancy for social reasons which entered into force on January 4, 1997 already in May 1997 was found by the Constitutional Tribunal as inconsistent with the then constitutional regulations. ${ }^{36}$ The Tribunal ruled that it makes the protection of life in the prenatal phase dependent on the decision of the ordinary legislator. Moreover, the Tribunal found that this contradiction to the constitution "legalises the termination of pregnancy without sufficient justification the need to protect another value, right or constitutional freedom and uses undefined criteria for this legalisation, thus violating constitutional guarantees for human life." ${ }^{37}$

Due to the existing balance of power in parliament in 1990s, no one really believed that the abortion compromise would be broken concerning the conflict between the interests of the Church and the state. For some, it was almost the myth of "abortion compromise" as they believed the majority of society would not accept a legal situation that is harmful to women. This is probably why no social issue has provoked open conflict between the main political groups like abortion in Poland. ${ }^{38}$

On July 5, 2016, the Committee "Stop Abortion" introduced to the Sejm, a bill prepared by the Ordo Iuris Institute for Legal Culture. It proposed to tighten the abortion law, providing for imprisonment for unlawful abortion in the case of fetal abnormality, that has constituted, so far, more than 98 percent of the total number of legal abortions each year. ${ }^{39}$ Just a month later, the Committee of the Legislative Initiative "Let's Save Women" submitted an opposition bill, proposing unlimited access to abortion until the end of the $12^{\text {th }}$ week of pregnancy. In response, on September 14, 2016 representatives of the Polish Federation of Life Defence Movements submitted a draft under the Act of 11 July 2014 on petitions, demanding the tightening of the abortion law, but without changing the solution in force at that time, which excluded a woman undergoing an abortion from a criminal sanction.

On September 23, 2016 the Sejm voted the bill liberalising the abortion law ("Let's Save Women"), and sent the radicalisation bill ("Stop abortion") for further work in committees. Officially, on October 3, 2016, Poland saw the largest strike since the $1980 \mathrm{~s}^{40}$, which was the culmination of a several-week-long protest action, lasted practically from the end of September. The protest actions, referred to as the Black Protest and National Women's Strikes adopted the formula of large demonstrations, protests and events in many Polish cities aimed at opposing changes of rights, and - importantly - increasing awareness related to reproductive rights ${ }^{41}$ Only three days later, the Sejm approved the parliamentary committee for justice and human rights' recommendation and finally 
rejected the draft "Stop Abortion" initiative at the meeting on October 6, 2016. In the end, the rejection of the civil bill was explained by the fact that further criminalisation of abortion would lead to trials that would have opposite effects than the bill intended. ${ }^{42}$

Subsequent attempts to amend the statutory provisions were made again in 2017-2018. In October 2017, the Committee of the Legislative Initiative "Let's Save Women 2017" once again submitted to the Sejm a civil bill asking for access to termination of pregnancy up to 12 weeks. The case was widely echoed, because both the committee of activists in favor of the restrictive abortion law, and the Catholic media were accused of lying about the scale of support for the actions of the "Let's Save Women 2017" committee (assessed by them at over 400,000 signatures). ${ }^{43}$ On October 27, that is two weeks before the citizens' bill was to be submitted to the Sejm, which removes one of the three conditions for performing an abortion from the 1993 Act, a group of MPs belonging mainly to the ruling party club, Law and Justice, and non-attached MPs, filed a motion with the Constitutional Tribunal. They have applied for a ruling that the provisions of the above-mentioned Act authorising abortion in the event of a high probability of severe and irreversible fetal impairment or an incurable disease threatening its life is inconsistent with the Polish Constitution. ${ }^{44}$

Following this initiative, on November 30, the "Stop Abortion" Legislative Initiative committee submitted to the Sejm a civil bill abolishing the right to abortion in the event of a high probability of severe and irreversible fetal impairment or an incurable life-threatening disease. At the beginning of the new year, on January 10, 2018, the first reading of both draft laws of the legislative initiatives "Let's Save Women 2017" and "Stop Abortion" took place. After the first reading, the Sejm draft initiative "Let's Save Women 2017" was rejected, while the draft "Stop Abortion" initiative was referred to a subcommittee specially appointed for this purpose. ${ }^{45}$

The application submitted on October 27, 2017 to the Constitutional Tribunal was aimed at limiting abortion on constitutional grounds. Undoubtedly, the Law and Justice party, which has been ruling in Poland since 2015, has tried to implement a total ban on abortion from the time they took power in Poland. ${ }^{46}$ Following the Tribunal's ruling on the non-compliance of the embryopathological premise of termination of pregnancy with section 38 of the Constitution, the country's largest demonstrations since 1989 exploded. Mass protests of Polish women and men reflected the radicalisation of attitudes and significant changes in society's attitude towards abortion that have taken place in recent years. ${ }^{47}$ Poles in several hundred cities in Poland and in over a hundred cities abroad (including Christchurch, New Zealand), expressed their opposition to the abortion ban. These protests were also directed at the ruling Law and Justice party as they were distinctly anti-government, anti-Catholic and pro-secular (the Polish episcopate supported the decision to tighten the abortion law). ${ }^{48}$ 
The demonstrators protested not only against the very content of the judgment of the Constitutional Tribunal, but also - which is no less important - against the form in which this body has been functioning. A number of doubts regarding the constitutionality of the process of appointing some judges to the Tribunal and the constitutionality of appointing the chairwoman of this body, Julia Przyłębska, have already been expressed by experts in the field of constitutional law and legal institutions. They have noticed legal flaws and questioned the legality of the Tribunal in general.

In the light of the Penal Code, ${ }^{49}$ the organisers of demonstrations during Covid-19 (a global pandemic) may be imprisoned for up to 8 years. The wave of protests flooded Polish cities again after the publication of the long-awaited justification of the Tribunal's ruling on abortion..$^{50}$ According to a survey conducted at the end of November 2020, as much as $66 \%$ of respondents were in favor of a woman's right to abortion until the $12^{\text {th }}$ week of pregnancy, while only $26 \%$ opposed. The Federation for Women and Family Planning calls the violation of reproductive rights in Poland a case of "institutional violence".

Even before the judgment of the Constitutional Tribunal on the admissibility of termination of pregnancy, in October 2020, over 600 doctors from all over Poland signed a letter to the judges of the Constitutional Tribunal, in which they appealed not to ban abortion due to severe and irreversible damage to the fetus or terminal disease. In this document, they referred to a significant threat to the physical and mental health of women. According to the facts, removal of the medical premise on termination of pregnancy due to fetal defects, which account $98 \%$ of all abortions, will worsen the quality of care provided to pregnant women and will negatively affect the conditions of practicing the medical profession. ${ }^{51}$

Nevertheless, according to the current legal status, abortion in Poland has become practically illegal. The person who performed the abortion (doctor); the person who provided assistance in performing the abortion and the person who persuaded the woman to terminate the pregnancy are criminally liable, while the woman who undergoes the abortion does not bear such responsibility. ${ }^{52}$

\section{The way into the 21st century: New Zealand's example of shifting abortion law from its criminal framework}

When the introduction of an abortion ban in Poland has become a fact, the new extremely liberal abortion law in New Zealand has been in force for almost a year. It accomplished something groundbreaking as it removed abortion from the crime list. New Zealand is an interesting case to study as one of non-Catholic majority countries in which, however, abortion-rights advocates were long unsuccessful in achieving lib- 
eral abortion reform. For the first time in 40 years New Zealand has modernized its abortion laws and de-criminalised abortion. Now abortion is legal and regulated under the health legislation. ${ }^{53}$

In fact, the legal situation regarding abortion has evolved over the years in New Zealand. This is evidenced by the fact that since the adoption of England's restrictive laws in 1840 , abortionists were considered criminals while women seeking abortion were considered an accomplice to the crime. The legacy of $19^{\text {th }}$ century English law that made abortion illegal in New Zealand proved to have a long-lasting and profound impact, as abortion laws remained unchanged until 1977.

The public debate intensified in 1970s when numerous anti-abortion and abortion rights groups emerged..$^{54}$ The impetus for legal changes was the opening of the first abortion clinic in New Zealand (the Auckland Medical Aid Centre, AMAC). In response to growing public debate around abortion, a Royal Commission on Contraception, Sterilisation and Abortion was set up to consider public policy on these socially sensitive issues. As a result of the Royal Commission's work - the Sterilisation and Abortion - the Contraception Sterilisation and Abortion Act (CS\&A) 1977 was adopted and established the legal framework for abortion in New Zealand for the next several decades. ${ }^{55}$

According to this Act, pregnancy could be terminated only in the event of a threat to the life and health of the mother or serious fetal defects and had to be approved by a doctor and two medical consultants. Despite the intention of Parliament in 1977 that abortion should not be available on request, it is arguable that in New Zealand on the ground of CS\&A we have had "de facto abortion on request". It has been suggested that some consultants approve almost every women's request, which would indicate that the laws were operating more liberally in practice than they were intended to. ${ }^{56}$

In 1977, the Crimes Act $1961^{57}$ was also amended to allow abortion within 20 weeks of pregnancy. After this period, abortion was permitted in order to save the mother's life and to prevent serious, permanent damage to her mental and physical health. In 1978, another amendment to the 1961 Act allowed for an abortion to save the mother's life, mental and physical health, abnormalities of the fetus in the $20^{\text {th }}$ week of pregnancy and incest or sexual intercourse with guardians and family members. In the light of this Act, such premises as rape, extreme age or various social and economic factors were not the basis for legal abortion in New Zealand. ${ }^{58}$

Subsequent attempts to reform the abortion law were made in the first years of the $21^{\text {st }}$ century. In July 2001, the Fifth Labour Government agreed to amend the Contraception, Sterilisation and Abortion Act 1977 to allow one doctor to approve an abortion. The proposed amendment also explored the grounds for the possible de-criminalization of abortion. Hovewer, those amendments to the existing legislation were not adopted due to the growing instability in the Labour - Alliance coalition government. ${ }^{59}$ 
The next important step in the way to liberalisation of abortion law in New Zealand concerned section 38 of the Care of Child Act $2004^{60}$ which permitted girls under the age of 16 to seek an abortion in accordance with the procedure specified in the CS\&A. Before the 2004 Act, however, there were no laws in force that would require for women under 18 seeking abortions to notify or obtain parents' consent. It is worth emphasising that among other non-urgent medical procedures, abortion was the only one that did not require such consent. Conservative National MP for Clevedon, Judith Collins, supported by the anti-abortion organisation Voice for Life, which was the primary mover of the amendment to this Act, welcomed the results of the Herald-DigiPoll. The survey showed that $71.1 \%$ of New Zealanders believed parents should be informed about whether or not their child was to have an abortion, with $60.7 \%$ believing this should be mandatory by law. ${ }^{61}$

In 2008, a former list MP, Gordon Copeland of the Kiwi Party introduced the Contraception, Sterilisation and Abortion (Informed Consent) Amendment Bill modeled on the Australian Capital Territory concept of Contraception, Sterilisation and Abortion (Informed consent). ${ }^{62}$ However, it was defeated on a voice vote in Parliament. Two years later, in July 2010, Labour MP, Steve Chadwick proposed the "Abortion Reform Act" with a view to remove the criminal status of abortion. A lack of sufficient parliamentary support for Chadwick's bill and strong opposition from Voice for Life made this initiative a failure. ${ }^{63}$

Undoubtedly, the wave of international changes to abortion laws in the second decade of the $21^{\text {st }}$ century led to the resumption of the abortion rights campaign in New Zealand, with a particular emphasis on decriminalising abortion. Following 2015, Abortion Law Reform Association of New Zealand (ALRANZ), the only significant abortion-rights lobbying group that started in 1971 after more radical Women's National Abortion Action Campaign (WONAAC) ceased its activities ${ }^{64}$, carried out a number of notable lobbying initiatives. One of them was the national poll on voters attitudes to abortion which showed that a majority of New Zealand voters supported legal abortion under all the given specific circumstances, such as the probability of a woman's death, the probability of fetal death, the difficult life situation of a woman, pregnancy resulted from rape or birth control failure. ${ }^{65}$

On February 27, 2018 the Minister of Justice, Andrew Little sought the advice of the New Zealand Law Commission for their advice on changes to the abortion legal framework. ${ }^{66}$ Just eight months later, ALRANZ together with six women with experiences of discrimination from seeking abortions in New Zealand issued a complaint to New Zealand's Human Rights Commission (HRC), challenging the existing abortion legal framework. ALRANZ representatives pointed out that abortion, which legally required the consent of two consultants, thus proving that the provisions on abortion violate human rights. According to ALRANZ, women were discriminated against as they were treated worse than other people using the health care system in New Zealand. 
Other significant initiatives of pro-abortion ALRANZ was an open letter to Parliament urging abortion law reform, signed by 35 organisations, including New Zealand Family Planning and Amnesty International New Zealand, and over 1500 famous personalities, including former Prime Minister Helen Clark. In addition, there were marches on Parliament in both 2018 and 2019, which gathered hundreds of protestors. ${ }^{67}$ On the other hand, anti-abortion groups that campaigned against changing New Zealand's abortion laws such as Family First NZ or not explicitly Catholic such as Voice for Life and Right to Life have had the institutional support from the Catholic Church. ${ }^{68}$ What is more, the Catholic doctrine had a disproportionate influence on New Zealand politics and policy. This was indicated in the report from the Royal Commission on Contraception, Sterilisation and Abortion from 1977 because most arguments based on church-based morality were used. ${ }^{69}$

The Catholic Church continues to dominate the anti-abortion movement in New Zealand in the $21^{\text {st }}$ century as well. However, even if Church funded anti-abortion lobbying groups increased their activity between the 1990s and 2010s, it did not result in any important electoral or legislative change success. Catholic bishops lobbied the Abortion Legislation Select Committee, making submission that was opposed to the Abortion Legislation Bill, however, to little effect. The position of the Catholic Church was based on the assumption that the proposed law effectively removed all legal protections for the unborn, especially as it was inconsistent with Section 182 of the Crimes Act that was still in force. ${ }^{70}$ That is why we can consider that the Church has considerably less influence in New Zealand now than in the 1970s.

Meanwhile, critical to criminalisation of abortion issue was the UN CEDAW Monitoring Committee, which in its complaint described the New Zealand abortion law as discriminating against women's human rights. However, before this case was passed to the Human Rights Review Tribunal, the Abortion Legislation Bill was introduced to Parliament. ${ }^{71}$ The United Nations Human Rights Council has also added its voice to the growing support for New Zealand removing abortion from the Crimes Act. During the third Universal Periodic Review (UPR), many UN member states recommended that New Zealand remove abortion from the Crimes Act and began to treat abortion as a health issue. The United Nations Human Rights Council in the content of its recommendations clearly indicated that abortion law is inconsistent with human rights treaties and international standards. The adoption of the final reports of the UPR in June 2019 obliged New Zealand to immediately respond to the recommendations it has received..$^{22}$

What both MPs, Copeland and Chadwick, were unable to do in the 2000s, Prime Minister Jacinda Ardern did. Her government has sought to align the national abortion legal framework with the health approach that fulfils Labour's 2017 election campaign intention. ${ }^{73}$ The passing of the bill is seen as a win for Ardern's centre-left coalition party, that was one of Prime Minister's promise when she was elected for the first time. However, 
at the time of the 2017 election, poll results conducted by the New Zealand Election Study also showed a majority of New Zealanders supported the right to access abortion on request. ${ }^{74}$ On this basis, it can be concluded that the Abortion Legislation Reform would finally be completed after Bill's final reading by a margin of 68 to $51 .^{75}$

Abortion is now available in New Zealand until the $20^{\text {th }}$ week of pregnancy and only a qualified health practitioner can provide an abortion. After 20 weeks, a pregnant woman would require a test and two doctors will have to agree an abortion is the right decision. Abortion, until recently the only medical procedure still on the New Zealand crime list, has now become, by repealing section 183 of the Crimes Act 1961, one of the legally offered medical services.

\section{Conclusions}

Poland and New Zealand are the countries where until recently abortions were the subject to a criminal sanction. Currently, in both of these legal orders we are dealing with a change, but it has gone in a completely different direction.

In New Zealand, which was the first country in the world to grant voting rights to women ${ }^{76}$ and main constitutional roles of Prime Minister, the Governor General and the Chief of Justice are now held by women, debates on liberalising of the abortion law have been somewhat muted. Given the extremely low public support for change (over 60,000 people signed a petition calling on New Zealand deputy-Prime Minister, Winston Peters, to ensure the Government withdrew the Bill) ${ }^{77}$, rapidly narrowing the gap between MPs opposing and supporting the Bill on the final stage of the legislative process should be considered as another success of Ardern's government - this time made during the Coronavirus pandemic. Abortion is now considered as a medical issue, not a moral one. In accordance with the applicable law, a woman no longer has to be assessed by a health practitioner for mental or physical wellbeing before $20^{\text {th }}$ week of pregnancy, which in the last 40 years of the restrictive abortion law was excessively abused.

The example of Poland is interesting as long as we consider the several decades of evolution of the abortion law, which was considered very liberal even in the pre-war years. From today's perspective, it can be measured at that stage of development only as moderately liberal, although compared to other Acts of this type in contemporary Europe, it could be one of the most permissive. The right to abortion has become one of the most important and social issues in recent years. Furthermore, the public mood has been radicalised against one of the most restrictive laws, under international law interpreted even as a form of violence against women. ${ }^{78}$ Polish women rebel against the deprivation of their right to make independent choices: realise their rights to decide about themselves. 
After 1989, the situation of women in Poland worsened. Women were burdened with the problems of the political transformation as economic and social reforms were considered to improve the situation of all social groups, while the actual impact on women's life situation was secondary. ${ }^{79}$ But women who have already gained economic and social power in many areas now are united, but by the fundamental issue: they did not agree that the legislation regarding abortion would deprive them of their free choice, namely the possibility of expressing their opposition to the entire system of reproductive rights in Poland.

And if we agree that the new abortion law in New Zealand truly reflects New Zealand in the $21^{\text {st }}$ century ${ }^{80}$, the Polish reality in which women are forced to risk their lives and give birth to children (including those who cannot be cured and have dysfunctions) takes the country back to pre-1989. According to UN experts, with this ruling, "(...) Poland has effectively slammed the door shut on legal abortion for women (...)" ${ }^{\prime 11}$ Indeed, Poland positions itself among the most severe of anti-abortion legislation within the developing countries of Africa, Latin America and the Middle East.

1 Paweł Kuczma, "Legal protection of life" in Implementation and protection of constitutional freedoms and rights of an individual in the Polish legal order. Mariusz Jabłoński, ed. (Wrocław: Faculty of Law, Administration and Economics of the University of Wrocław, 2014), pp. 37 -38.

2 The UN Human Rights Council Working group claims that unsafe abortions cause the deaths of around 47,000 women each year, whereas five million can suffer some form of temporary or permanent disability. See "Access to legal abortion services needed, to prevent 47,000 women dying each year - UN rights experts," 28 September 2018, UN News. Available at https://news.un.org/en/story/2018/09/1021332

3 Currently 25 million are unsafe abortions, among them 8 million were carried out in the least- safe or even dangerous conditions. It is worth adding that unsafe abortions lead to about further 7 million complications, entailing social and financial costs to women, their families, communities and health systems. See "Preventing unsafe abortion," Evidence brief, 2019. Available at https://www.who.int/ reproductivehealth/publications/preventing-unsafe-abortion-evidence-brief/en/

4 "Abortion regulations in the world: in Poland, the law is stricter than in Iran or Pakistan," 27 January 2021, National Geographic Poland. Available at https://www.national-geographic.pl/artykul/przepisyaborcyjne-na-swiecie-w-polsce-prawo-surowsze-niz-w-iranie-czy-pakistanie?page=2

5 M. Berer, "Abortion Law and Policy Around the World: In Search of Decriminalization," Health and Human Rights Journal, 19 (1) (June 2017), pp. 15 - 16.

6 Wanda Nowicka, Joanna Regulska, "Repressive Policies and Women's Reproductive Choices in Poland: The Case of State Violence Against Women" in Women's Journey to empowerement in the $21^{\text {st }}$ Century: A Transnational Feminist Analysis of Women's Lives in Modern Times. Kristen Zaleski, Annalisa Enrile, Eugenia L. Weiss \& Xiying Wang, eds. (Oxford Scholarship Online, October 2019, pp. 234 -235 .

7 Section 233 of the 1932 Penal Code, Journal of Laws 1932 No. 60, item 571.

8 Section 12 (1) of the Ordinance of the President of the Republic of Poland of 25 September 1932, Journal of Laws 1932 No. 81, item. 712. 
9 German occupation authorities legalised abortion in Poland on the basis of the ordinance of March 9, 1943. See "On March 9, 1943, Hitler introduces abortion in Poland," 9 March 2016, Interia Nowa Historia. Available at https://nowahistoria.interia.pl/kartka-z-kalendarza/news-9-marca-1943-r-hitlerwprowadza-aborcje-na-terenach-polski,nId,2159191

10 T. Chelouche, "Doctors, Pregnancy, Childbirth and Abortion during the Third Reich," Israel Medical Association Journal, 9, March 2007, pp. 202 - 203.

11 Section 66 (2) of the Constitution of the People's Republic of Poland adopted by the Legislative Sejm on July 22, 1952, Journal of Laws 1952 No. 33, item 232.

12 Section 2 of the Instruction of the Minister of health of 27 July 1954 on the necessity to perform an abortion due to the health of a pregnant woman, Polish Monitor 1954 No. 75, item 906.

13 Section 1 (1) of the Act of 27 April 1956, Journal of Laws 1956 No. 12, item 61.

14 These provisions were deleted on January 1, 1970 with the entry into force for the new Penal Code. See the Act of 19 April 1969 Penal Code, Journal of Laws 1969 No. 13, item 94.

15 Section 1 (3) of the Regulation of the Minister of Health of 11 May 1956 on termination or pregnancy, Journal of Laws 1956 No.13, item 68.

16 It is estimated that about 300,000 "underground" abortions took place in the first half of the 1950s. With the entry into force of the 1956 Act, the number of medical abortions increased significantly, reaching its peak in 1961. From around the mid-1960s, the number of abortions performed in Poland began to gradually decline. From the beginning of the 1970s, the average number of abortions was in the range of 300,000-500,000 per year. See A. Ignaciuk, "This harmful procedure." Discourses on abortion in the publications of the Society for Conscious Motherhood / Family Planning Society (1956-1980)," Journals of Wrocław Ethnology, 1 (20) (2014), pp. 81-83.

17 Section 3 (1) of the Regulation of the Minister of Health of 19 December 1959 on termination of pregnancy, Journal of Laws 1960 No. 2, item 15.

18 Ultimately, the 1956 Act expired on September 27, 1997 due to the repeal of the act on the medical profession. See the Act of December 5, 1996 on the Professions of Physician and Dentist, Journal of Laws 1997 No. 28 item. 152.

19 See draft resolution on the $40^{\text {th }}$ anniversary of the establishment and commencement of operations by the Polish Committee for the Defense of Life, Family and Nation, Warsaw, September 21, 2017. Available at https://www.senat.gov.pl/prace/druki/record,8771.html

20 Andrzej Friszke, An oasis at Copernicus. Catholic Intelligence Club 1956-1989, (Warszawa: Library of "Więzi", 1997), pp. 292 - 293, 217.

21 J. Gardawski, A. Mrozowicki, J. Czarzasty, „History and present of trade unions in Poland,” Dialog, 3 (2012), p. 5.

22 See Program Resolution of the $1^{\text {st }}$ National Congress of Delegates, 10 September 1991. Available at http://www.solidarnosc.org.pl/dok/wp-content/uploads/2012/09/I-KZD-uchwalaprogramowa.pdf

23 The Catholic Intelligentsia Club in the 1980s represented Christian-democratic groups within the opposition. They collaborated with representatives of political circles without a clear ideological face, such as the Workers' Defence Committee, the Society for Scientific Courses or "Solidarity", along with the media related to them and editorial offices of major journals. See P. Wierzbicki, "Ideological divisions within the political opposition in the People's Republic of Poland (PRL) in the years 1976-1989, " Memory and Justice, 1 (21) (2013), pp. 112 - 113, 116.

24 Marcin Kościelniak, "Transformation and abortion. Genealogy of the "abortion compromise," View. Theories and Practices of Visual Culture, 27 (2020), p. 9., DOI:10.36854/widok/2020.27.2247, p. 7.

25 Paulina Codogni, The June 1989 elections. On the threshold of political transformation, (Warszawa, IPN Institute of National Remembrance, 2012), p. 140.

26 Mirosław Chałubiński, ed. Politics and abortion, (Warszawa: Scholar Agency, 1994), pp. 99, 131.

27 This was confirmed by the results of a survey by the Public Opinion Research Center (TNS OBOP) in May 1989. When asked about their support for the bill, the respondents were divided almost equally: 46 percent in favor, 44 percent against. See Marcin Kościelniak, p. 9. 
28 Since 1999, the Federation has had the status of an advisory organization at the United Nations Economic and Social Council (ECOSOC). See Federation for Women and Family Planning, 5 February 2021. Available at https://en.federa.org.pl/about-us/

29 E. Markiewicz, I. Skawina, "Personalistic approach in family education on the background current education systems," Family Pedagogy, 4(4) (2014), p. 81.

30 Section 4a of the Act of 7 January 1993, Journal of Laws 1993 No. 17, item 78.

31 "A quarter of a century of abortion ban. 25 years ago, the Sejm adopted one of the most restrictive laws in Europe. Komorowski supported her, while Tusk was against it" 7 January 2018, OKO.press.

Available at https://oko.press/cwierc-wieku-zakazu-aborcji-25-temu-sejm-przyjal-jedna-najbardziej-restrykcyjnych-ustaw-europie-popieral-ja-komorowski-przeciw-byl-tusk/

32 “Abortion compromise?," 19 November 2006, Weeks Review. Available at https://www.tygodnikprzeglad.pl/aborcyjny-kompromis/

33 In Europe, such regulations are valid only in the Principality of Liechtenstein and the Principality of Monaco, in the world, among others in Colombia, Eritrea, Israel, Saudi Arabia and Pakistan. See The World's Abortion Laws, 26 April 2019, Center for Reproductive Rights. Available at https://reproductiverights.org/worldabortionlaws

34 Section 1 of the Act of August 30, 1996 amending the act on family planning and protection of the human fetus and conditions for allowing termination of pregnancy and on Amending Certain Other Acts, Journal of Laws 1996 no. 139 item 646.

35 Piotr Zamelski, "Protection of the child's right to life - selected issues" in Propaedeutics of human rights. Children's rights in the family and education. S. L. Stadniczeńko, ed. (Opole: Publishing House of the University of Opole, 2012), p. 105.

36 Constitutional Act of October 17, 1992 on mutual relations between the legislative and executive authorities of the Republic of Poland and on local self-government, Journal of Laws 1992 No. 84, item. 426.

37 See Announcement of the President of the Constitutional Tribunal of 18 December 1997, Journal of Laws 1997 No. 157, item. 1040, issued on the basis of the judgment of the Constitutional Tribunal dated May 28, 1997, docket number K26/96.

38 "In Poland, Protests Over Abortion Ban Could Revolutionize Politics," 7 December 2002, The New York Times. Available at https://www.nytimes.com/2020/12/07/world/europe/poland-abortion-protests. html

39 "Poland has slammed door shut on legal and safe abortions - UN experts," https://www.ohchr.org/, 27 October 2020. Available at https://www.ohchr.org/en/NewsEvents/Pages/DisplayNews.aspx?News$\mathrm{ID}=26434 \&$ LangID $=\mathrm{E}$

40 The Black Monday, the strike of Polish women, had a clear reference to Long Friday, October 24, 1975 in Iceland. As part of a nationwide protest approximately $90 \%$ of Icelandic women gave up household chores for one day and gainful employment. The aim of that action was to draw the attention of men to the value of women and the work they perform. The strike resulted in a significant social change - in 1980 , for the first time in the world, a woman was elected to a position president in general election (Vigdís Finnbogadóttir). Today Iceland is perceived in the world as the friendliest country for women. Their employment is $76 \%$, the state provides 9 months of maternity leave that are shared by parents, and the pay gap is practically non-existent. See "Long Friday" - 40 years behind Iceland," 24 October 2015, Strajk portal. Available at https://strajk.eu/dlugi-piatek-40-lat-za-islandia/

41 Elżbieta Korolczuk, Beata Kowalska, Radosław Nawojski, Jennifer Ramme, Claudia Snochowska-Gonzalez, "Mobilising women in 2016-2018: causes, contexts and research perspectives" in Women's rebellion. Black Protests and Women's Strikes. Elżbieta Korolczuk, Beata Kowalska, Jennifer Ramme, Claudia Snochowska-Gonzalez, eds. (Gdańsk: European Solidarity Centre, 2018), pp. 18-23.

42 "A complete ban on abortion to the bin. The Sejm finally rejected the bill," 6 October 2016, TVN24. Available at https://tvn24.pl/polska/sejm-odrzucil-projekt-ws-calkowitego-zakazu-aborcji-ra681648-3195405

43 See "The "Save Women" committee signed over 400,000 signatures," 23 October 2017. Available at https://www.polskieradio.pl/5/3/Artykul/1897374,Komitet-Ratujmy-Kobiety-zlozyl-ponad-400-tysiecy-podpisow; "Half a million Poles for abortion? The truth is quite different," 4 December 2017. Available at https://www.gosc.pl/doc/4332340.Pol-miliona-Polakow-za-aborcja-Prawda-jest-zupelnie-inna 
44 "The Constitutional Tribunal will check whether the anti-abortion act is consistent with the Constitution. In 1997, the regulations were tightened this way," 3 November 2017. Available at https://oko.press/ trybunal-konstytucyjny-sprawdzi-ustawa-antyaborcyjna-zgodna-konstytucja-1997-r-sposob-zaostrzono-przepisy/

45 These events were accompanied by a wave of protests organised by the National Women's Strike. As of March 8, 2017, the international women's strike which took place in 80 towns and cities continued "Black Protests" of October 2016. The next protest was held on 23 March 2018 in Warsaw. According to the data of the City Hall on Black Friday 55,000 people were present on the streets of the Polish capital (although, according to the estimates of the organisers even 90,000 people). See Aneta Ostaszewska, "Black protests - a struggle for women's subjectivity," Polish Journal of Educational Studies, I (LXXI) (2018), pp. $95-96$.

46 See Law and Justice Program 2019: Polish model of the welfare state. Available at http://pis.org.pl/ dokumenty

47 While in March 2016 only 14\% of Poles and Polish women declared that abortion should be allowed not only in cases specified in the act, but also when a woman is in a difficult situation, in October 2016 this opinion was already expressed by $20 \%$ of respondents (CBOS 2016). In 2018, in a survey by the SW Research Agency, $46 \%$ of respondents believed that abortion should be allowed up to the $12^{\text {th }}$ week of pregnancy “on demand" (OKO Press 2018). See Elżbieta Korolczuk, Beata Kowalska, Radosław Nawojski, Jennifer Ramme, Claudia Snochowska-Gonzalez, p. 23.

48 "In Poland, Protests Over Abortion Ban Could Revolutionize Politics," 7 December 2002.

49 Section 165 (1) of the 1997 Penal Code, Journal of Laws 1997 No. 88, item 553.

50 It didn't happen until January 27, 2021. See Judgment of the Constitutional Tribunal dated October 22, 2020, docket number K 1/20, Journal of Laws 2021 item 175.

51 See Open letter of doctors to the judges of the Constitutional Tribunal. Available at https://www. ofeminin.pl/swiat-kobiet/to-dla-nas-wazne/lekarze-protestuja-przeciwko-zmianom-w-prawie-aborcyjnym-list/1cwkq35

52 According to the current text of the 1993 Act, legal abortion in Poland is possible only when the pregnancy threatens the mother's life or health (the so-called therapeutic premise) and when it arose as a result of a prohibited act, for example rape or incest (the so-called legal premise).

53 These laws are: Health and Disability Commissioner Act 1994 and the Code of Health and Disability Services Consumers' Rights; Health Practitioners Competence Assurance Act 2003; Medicines Act 1981; Health and Disability Services (Safety) Act 2001 and Health and Safety at Work Act 2015. See Abortion Law, New Zealand Family Planning. Available at https://www.familyplanning.org.nz/advice/abortion/ abortion-law

54 That period is known as the time of the abortion wars. See A. McCulloch \& A. Weatherall (2017), "The fragility of de facto abortion on demand in New Zealand Aotearoa", Feminism \& Psychology, 27:1 (2017), p. 95., DOI: 10.1177/0959353516679432.

55 Contraception, Sterilisation and Abortion Act 1977, 1977 No. 112.

56 In 2008 as much as $99 \%$ of abortions requested were said to be authorised. See A. McCulloch \& A. Weatherall, pp. $93-94$.

57 Crimes Act 1961, 1961 No. 43.

58 A. McCulloch \& A. Weatherall, p. 93.

59 Alison McCulloch, Fighting to Choose: The Abortion Rights Struggle in New Zealand, (Wellington, Victoria University Press, 2013), p. 262.

60 Care of Child Act 2004, 2004 No. 90.

61 "Abortion poll backs rights of parents," 28 September 2004. Available at https://www.nzherald. co.nz/nz/abortion-poll-backs-rights-of-parents/GILYI4EM73UEC4242NAJFY37OM/

62 It is noteworthy that amongst these jurisdictions that have abortion legislation, the Australian state of Victoria has currently the most extreme law. In practice, it allows for abortion on demand, for any reason throughout the pregnancy. See "NZ PM rushes world's most extreme abortion legislation into law while country distracted with pandemic," 18 March 2020, Available at https://righttolife.org.uk/news/nz-pmrushes-worlds-most-extreme-abortion-law-into-law-while-country-distracted-with-pandemic

63 "MP's bill aims for abortion on demand," 2 July 2010. Available at https://www.nzherald.co.nz/nz/ mps-bill-aims-for-abortion-on-demand/MCQAWPDZEDE4GZOFHAB3NVKY2Y/ 
64 "Abortion - Opposition and support from the 1960s'," Te Ara - the Encyclopedia of New Zealand, 5 May 2011, https://teara.govt.nz/en/abortion/page-3

65 “Abortion Issues Poll January 2017," 31 January 2017. Available at http://alranz.org/wp-content/ uploads/2017/02/Abortion-Issues-Poll-Results-January-2017.pdf

66 "Alternative approaches to abortion law," 27 February 2018. Available at https://www.lawcom.govt. nz/abortion

67 "Hundreds march on Parliament calling for abortion law reform," Staff.co.nz, 5 December 2018. Available at https://www.stuff.co.nz/national/health/109128499/hundreds-march-on-parliament-callingfor-abortion-law-reform; "Organisations sign letter supporting abortion law reform as second reading to begin, " 3 March 2020. Available at https://www.stuff.co.nz/national/health/119969499/organisations-sign-letter-supporting-abortion-law-reform-as-second-reading-to-begin

68 “Abortion - Abortion: 1990s to 21st century," Te Ara - the Encyclopedia of New Zealand, 5 May 2011, https://teara.govt.nz/en/abortion/page-5

69 One of them was that "the unborn child, as one of the weakest, the most vulnerable, and most defenseless forms of humanity, should receive protection.". See "New Zealand abortion bill 'totally unacceptable', bishops say," 20 February 2020. Available at https://www.catholicnewsagency.com/news/ new-zealand-abortion-bill-totally-unacceptable-bishops-say-15449

70 Joint submission by the New Zealand Catholic Bishops Conference \& The Nathaniel Centre, September 2019. Available at https://www.parliament.nz/resource/en-NZ/52SCAL_EVI_89814_AL6911/ f0dc02fbf85601b45c8acc8c1 fcecba0e73b69a2

71 “Abortion case headed for Human Rights Tribunal," Newsroom.co.nz, 8 October 2018. Available at https://www.newsroom.co.nz/2018/10/07/267802/abortion-case-before-human-rights-commission

72 "UN recommends abortion law changes: Agencies welcome UN review recommendations," 26 January 2019. Available at https://www.familyplanning.org.nz/news/2019/un-recommends-abortion-decriminalisation

73 "New Government bill seeks to remove abortion from Crimes Act, treat it as a health issue," 5 August 2019. Available at https://www.tvnz.co.nz/one-news/new-zealand/new-government-bill-seeks-remove-abortion-crimes-act-treat-health-issue

74 A 2017 survey showed $63.3 \%$ of New Zealanders disagreed with the statement "abortion is always wrong", an increase from 55.4\% in 2008. See "New Zealand Election Study," 19 August 2019. Available at http://www.nzes.org/exec/show/index

75 Abortion Legislation Act 2020, 2020 No. 6.

76 G.A. Wood, Chris Rudd, The Politics and Government of New Zealand, (Dunedin, University of Otago Press, 2004), p. 243.

77 "NZ PM rushes world's most extreme abortion legislation into law while country distracted with pandemic," 18 March 2020.

78 K. Kędziora, "Reproductive rights and discrimination against women. Polish anti-abortion act in the light of international law standards," Available at http://www.ptpa.org.pl/site/assets/files/1028/opinia_prawa_reprodukcyjne_a_dyskryminacja_kobiet.pdf

79 Wojciech Stankiewicz, "The legal status of women in Poland in the light of the European Union legislation," Central European Political Studies, 1 (2006), p. 114., DOI: 10.14746/ssp.2006.1.07.

80 "This week we brought New Zealand's abortion laws into the 21st century," 19 March 2020. Available at https://www.theguardian.com/world/commentisfree/2020/mar/20/this-week-we-brought-new-zealands-abortion-laws-into-the-21st-century

81 "Poland has slammed door shut on legal and safe abortions - UN experts," 27 October 2020. 